\title{
Pembatalan Akta Jual Beli Hak Atas Tanah Dan Akta Pemberian Hak Tanggungan Berdasar Putusan Pengadilan (Studi Putusan Perkara Nomor 93/Pdt/2016/PT.Yyk)
}

\section{Devendra Dovianda Priyono}

Magister Kenotariatan Fakultas Hukum Universitas Islam Indonesia Yogyakarta Indonesia Jln. Cik Di Tiro No. 1 Terban, Gondokusuman, Daerah Istimewa Yogyakarta Indonesia doviandadevendra@gmail.com

Key Word:
Cancelation;
mortgage right; sale
and purchase of land
right
right

\begin{abstract}
There are two problem formulations in this study, namely: first, how is the application of the precautionary principle by PPAT in making the deed of sale and purchase of land rights and the deed of granting mortgage rights? Second, what are the legal considerations used by the judge in deciding the cancellation of the deed of sale and purchase of land rights and the deed of granting mortgage? The type of this research is empirical, by using a case approach that is supported by interviewing sourceperson. Data analysis in this legal research uses qualitative analysis. The sourceperson in this legal research in PPAT located in the area of Yogyakarta City, Bantul Regency, and Kulonprogo Regency. The results of this study conclude that, first, PPAT in the making of the deed of sale and purchase of land rights and the deed of granting mortgage rights are obliged to apply the precautionary principle to avoid issues that may harm the parties and to avoid the PPAT deed being canceled and declared null and void. Second, the legal considerations used by the judge to cancel the PPAT deed is due to the buyer committed an unlawful act and abused the situation against an elderly seller who was sick, lived alone and could not read and write hence being lied to by the buyer.
\end{abstract}

\section{Kata-kata Kunci: \\ Akta jual beli hak atas tanah; akta pemberian hak tanggungan; pembatalan}

Abstrak

Terdapat dua rumusan masalah dalam penelitian ini yakni: pertama, bagaimana penerapan prinsip kehati-hatian oleh PPAT dalam pembuatan akta jual beli hak atas tanah dan akta pemberian hak tanggungan? Kedua, dasar pertimbangan hukum apakah yang digunakan hakim dalam memutus pembatalan akta jual beli hak atas tanah dan akta pemberian hak tanggungan? Jenis penelitian ini adalah empiris, dengan menggunakan pendekatan kasus yang didukung dengan wawancara narasumber. Analisis data dalam penelitian hukum ini menggunakan analisis kualitatif. Narasumber di dalam penelitian hukum ini adalah PPAT yang berada di wilayah Kota Yogyakarta, Kabupaten Bantul, dan Kabupaten Kulonprogo. Hasil penelitian ini menyimpulkan, pertama, bahwa PPAT dalam membuat akta jual beli hak atas tanah dan akta pemberian hak tanggungan harus menerapkan prinsip kehati-hatian untuk menghindari permasalahan yang timbul dan merugikan para pihak serta untuk menghindari akta PPAT tersebut dibatalkan dan menjadi tidak berkekuatan hukum. Kedua, dasar pertimbangan hukum yang digunakan hakim untuk membatalkan akta PPAT tersebut karena pembeli melakukan perbuatan melawan hukum dan penyalahgunaan keadaan terhadap penjual yang sudah lanjut usia yang dalam keadaan sakit, tinggal sendirian dan tidak bisa baca tulis dengan dibohongi kata-kata oleh pembeli.

\section{Pendahuluan}

Jabatan Notaris/PPAT merupakan jabatan kepercayaan yang harus selaras dengan mereka yang menjalankan tugas jabatan tersebut sebagai orang yang dipercaya. 
Notaris/PPAT sebagai jabatan yang kepercayaan tidak berarti apa-apa jika ternyata dalam menjalankan tugas jabatannya adalah orang yang tidak dapat dipercaya, dalam hal ini antara jabatan notaris dan PPAT harus sejalan bagaikan dua sisi mata uang yang tidak dapat dipisahkan. ${ }^{1}$ Keberadaan notaris pada masa sekarang dinilai sangat penting karena hampir segala urusan manusia yang berkaitan dengan jual beli, perjanjian, sewa menyewa, waris dan masih banyak lagi serta tuntutan masyarakat akan kepastian hukum menjadikan notaris sebagai pejabat umum yang mempunyai kewenangan untuk membuat akta autentik sebagai suatu alat bukti yang sah sangat dibutuhkan oleh masyarakat. Sedangkan yang dimaksud dengan akta autentik adalah suatu akta yang didalam bentuk yang ditentukan undang undang, dibuat oleh atau dihadapan pegawaipegawai umum yang berkuasa untuk itu dtempat dimana akta dibuat.

Akta autentik dibuat dihadapan atau oleh notaris/PPAT berkedudukan sebagai akta Autentik menurut bentuk dan tata cara yang ditetapkan dalam Undang-Undang Jabatan Notaris, menurut Irawan Soerodjo, bahwa ada 3 unsur esensialia agar terpenuhinya syarat formal suatu akta autentik, yaitu: ${ }^{2}$

1. Didalam bentuk yang ditentukan oleh Undang-Undang;

2. Dibuat oleh dan dihadapan Pejabat Umum;

3. Akta yang dibuat oleh atau dihadapan Pejabat Umum yang berwenang untuk itu dan ditempat dimana akta itu dibuat.

Suatu akta autentik hanya dapat dibuat oleh dan atau dihadapan pegawai-pegawai umum yang memiliki kewenangan untuk membuat akta Autentik tersebut ditempat dimana akta autentik tersebut dibuat. Kalau berbicara mengenai akta Autentik tentunya tidak terlepas dari notaris, karena notaris sendiri pun memiliki kewenangan untuk membuat akta autentik dimana tercantum didalam UUJN. Namun selain notaris, ada juga Pejabat Pembuat Akta Tanah atau biasa disebut PPAT, PPAT juga memiliki kewenangan untuk membuat suatu akta autentik yang mana dijelaskan pada Peraturan Pemerintah Republik Indonesia Nomor 37 Tahun 1998 tentang Peraturan Jabatan Pejabat Pembuat Akta Tanah menyebutkan bahwa Pejabat Pembuat Akta Tanah selanjutnya disebut PPAT adalah pejabat umum yang diberi kewenangan untuk membuat akta-akta autentik mengenai perbuatan hukum tertentu mengenai hak atas tanah atau hak milik atas satuan rumah susun. PPAT termasuk pejabat umum yang khusus membuat akta yang berkaitan peralihan hak atas tanah.

Selain itu PPAT juga disebut di dalam Undang-Undang Nomor 4 Tahun 1996 tentang Hak Tanggungan atas Tanah beserta benda-benda yang berkaitan dengan tanah, Pasal 1 angka 4 bahwa Pejabat Pembuat Akta Tanah (PPAT) adalah pejabat umum yang diberi wewenang untuk membuat akta pemindahan hak atas tanah, akta pembebanan hak atas tanah, dan akta pemberian kuasa membebankan hak tanggungan menurut peraturan perundang-undangan yang berlaku. Akta pemberian hak tanggungan sendiri adalah akta PPAT yang berisi pemberian hak tanggungan kepada kreditor tertentu sebagai jaminan untuk pelunasan piutangnya.

1 Habib Adjie, Sanksi Perdata dan Administratif Terhadap Notaris Sebagai Pejabat Publik, Refika Aditama, Bandung, 2009, hlm. 83.

${ }^{2}$ Irawan Soerodjo, Kepastian Hukum Hak Atas Tanah di Indonesia, Arkola, Surabaya, 2003, hlm. 148. 
PPAT tersebut diberikan wewenang untuk membuat akta pemindahan hak atas tanah, akta pembebanan hak atas tanah, dan pemberian kuasa membebankan hak tanggungan menurut peraturan perundang-undangan yang berlaku. Notaris/PPAT dalam melakukan suatu tindakan hukum harus senantiasa bertindak secara hati-hati agar notaris/PPAT sebelum mengambil keputusan meneliti semua fakta yang relevan dalam pertimbangannya berdasarkan kepada peraturan perundang-undangan yang berlaku. Meneliti semua kelengkapan dan keabsahan alat bukti atau dokumen yang diperlihatkkan kepada notaris, serta mendengar keterangan atau pernyataan para penghadap wajib dilakukan sebagai dasar pertimbangan untuk dituangkan di dalam akta. Asas kehati-hatian adalah suatu asas yang menyatakan bahwa notaris/PPAT dalam menjalankan fungsi dan jabatannya wajib menerapkan prinsip kehati-hatian dalam rangka melindungi kepentingan masyarakat yang dipercayakan padanya. ${ }^{3}$ Tujuan diberlakukannya prinsip kehati-hatian tidak lain adalah agar notaris selalu dalam raburambu yang benar. Dengan diberlakukannya prinsip kehati-hatian diharapkan agar kepercayaan masyarakat kepada notaris/PPAT tetap tinggi.

Selain itu didalam jabatannya mempunyai kewajiban untuk selalu bertindak jujur, teliti, penuh rasa tanggung jawab, mandiri dan tidak memihak salah satu pihak. Tidak dapat dipungkiri bahwa pada saat ini ada notaris maupun PPAT yang terjerat perkara di pengadilan baik dari perkara perdata maupun perkara pidana, salah satunya adalah karena perbuatan melawan hukum. Pasal 1365 Kitab Undang-Undang Hukum Perdata memberikan pengertian bahwa yang dimaksud dengan perbuatan melawan hukum adalah setiap perbuatan melanggar hukum dan membawa kerugian kepada orang lain, mewajibkan orang yang menimbulkan kerugian itu karena kesalahannya untuk mengganti kerugian tersebut. Pasal 1366 secara lebih lanjut mengatur bahwa setiap orang bertanggungjawab bukan hanya atas kerugian yang disebabkan perbuatan-perbuatan, melainkan juga atas kerugian yang disebabkan kelalaian atau kesembronoannya (kurang hati-hati).

\section{Rumusan Masalah}

Berdasarkan uraian di atas, terdapat 2 rumusan masalah dalam penelitian ini yakni, pertama, bagaimana penerapan prinsip kehati-hatian yang diterapkan PPAT dalam pembuatan akta jual beli hak atas tanah dan akta pemberian hak tanggungan? Kedua, dasar pertimbangan hukum apakah yang digunakan hakim dalam memutus pembatalan akta jual beli hak atas tanah dan akta pemberian hak tanggungan dan tepatkan dasar pertimbangan tersebut?

\section{Tujuan Penelitian}

Terdapat dua tujuan dalam penelitian ini yakni, pertama, mengetahui bagaimana penerapan prinsip kehati-hatian yang diterapkan PPAT dalam pembuatan akta jual beli hak atas tanah dan akta pemberian hak tanggungan. Kedua, mengetahui dan

${ }^{3}$ M. Luthfan Hadi Darus, Hukum Notariat dan Tanggungjawab Jabatan Notaris, UII Press, Yogyakarta, 2017, hlm. 39. 
menganalisis dasar pertimbangan yang digunakan hakim dalam memutus perkara tersebut dan tepatkah dasar pertimbangan tersebut.

\section{Metode Penelitian}

Pada metode penelitian ini, jenis penelitian yang digunakan adalah empiris dengan menggunakan metode pendekatan kasus, yaitu pendekatan yang dilakukan dengan cara melakukan telaah terhadap kasus-kasus yang berkaitan dengan isu yang dihadapi yang telah menjadi putusan pengadilan yang telah mempunyai kekuatan yang tetap. ${ }^{4}$ Sumber data primer yaitu berhubungan dengan peraturan-perundang-undangan dan putusan pengadilan. Sumber data sekunder yaitu bahan yang memberikan penjelasan mengenai bahan hukum primer berupa hasil penelitian artikel, buku-buku, referensi dan media informasi lainnya. Cara pengambilan data yaitu dengan melakukan wawancara dengan PPAT sebagai narasumber. Lokasi penelitian dilakukan di Kota Yogyakarta, Kabupaten Bantul, dan Kabupaten Kulonprogo. Teknik analisis data menggunakan metode kualitatif yaitu metode analisis data dengan cara mengelompokkan dan menyeleksi data yang diperoleh dari penelitian lapangan menurut kualitas dan kebenarannya kemudian disusun secara sistematis yang selanjutnya dikaji dengan metode berfikir deduktif dihubungkan dengan teori, kemudian dibuat kesimpulan yang berguna untuk menjawab rumusan masalah dalam penelitian ini. ${ }^{5}$

\section{Hasil Penelitian dan Pembahasan}

Untuk permasalahan yang pertama, notaris/PPAT dalam melakukan suatu tindakan hukum harus senantiasa bertindak secara hati-hati agar notaris/PPAT sebelum membuat akta harus meneliti semua fakta yang relevan dalam pertimbangannya berdasarkan kepada perundang-undangan yang berlaku, meneliti semua kelengkapan dan keabsahan alat bukti atau dokumen yang diperlihatkan kepada notaris/PPAT serta mendengar keterangan atau pernyataan para penghadap wajib dilakukan sebagai dasar pertimbangan untuk dituangkan didalam akta, apabila notaris/PPAT kurang teliti dalam memeriksa fakta-fakta penting itu berarti notaris/PPAT bertindak tidak hati-hati. ${ }^{6}$ PPAT dalam menjalankan tugas jabatannya diperlukan kehati-hatian dari PPAT itu sendiri dalam menerima pekerjaan ataupun klien. Ketika PPAT merasa ragu atau kurang yakin terhadap para pihak atau klien tersebut PPAT wajib dan berhak untuk menggali dan mencari tahu informasi yang lebih banyak lagi karena PPAT hanya mnerima bukti formil, agar supaya tidak ada pihak yang merasa dirugikan setelah terjadi suatu perikatan atau pembuatan akta PPAT, dan bahkan PPAT dapat menolak klien tersebut apabila masih tetap ragu atau tidak yakin terhadap klien tersebut, hal itu dilakukan untuk menghindari adanya pihak yang dirugikan nantinya.

PPAT dalam praktiknya ketika membuat akta jual beli hak atas tanah dan akta pemberian hak tanggungan harus menerapkan prinsip kehati-hatian sebagaimana telah

${ }^{4}$ Peter Mahmud Marzuki, Penelitian Hukum, Kencana, Jakarta, 2017, hlm. 134.

5 Abdul Kadir Muhammad, Hukum dan Penelitian Hukum, Citra Aditya Bakti, Bandung, 2004, hlm. 50

${ }^{6}$ Fikri Ariesta R, "Penerapan Prinsip Kehati-hatian Notaris Dalam Mengenal Para Penghadap", Lex Renaissance, Vol. 3, No. 2, 2018, hlm. 3. 
diatur didalam Pasal 22 Peraturan Pemerintah Nomor 37 Tahun 1998 bahwa akta PPAT harus dibacakan/dijelaskan isinya kepada para pihak dengan dihadiri oleh sekurangkurangnya 2 orang saksi sebelum ditandatangani seketika itu juga oleh para pihak, saksisaksi, dan PPAT.

Dari 3 narasumber yang telah peneliti wawancara dapat diambil kesimpulan bahwa prinsip kehati-hatian sangatlah penting diterapkan atau dilakukan oleh PPAT dalam menjalankan tugas jabatannya. Hal ini karena jika tidak diterapkan akan mengakibatkan permasalahan hukum yang mengakibatkan kerugian kepada salah satu pihak karena kesalahan PPAT yang tidak bertindak hati-hati. Penerapan prinsip kehatihatian dilakukan mandiri oleh PPAT berkreasi dan bertanya sedetail mungkin guna menjamin syarat formil dan materil baik subjek maupun objeknya terpenuhi yang berkaitan dengan pembuatan akta jual beli hak atas tanah dan akta pemberian hak tanggungan. Apabila PPAT tidak menerapkan prinsip kehati-hatian dan mengakibatkan kerugian para pihak yang disebabkan oleh kesalahan PPAT dalam membuat akta, maka risiko yang akan didapatkannya yaitu akta tersebut dapat dibatalkan jika melanggar syarat subjektif yang diatur dalam Pasal 1320 KUHPerdata dan batal demi hukum jika melanggar syarat objektif, kemudian akta tersebut hanya akan menjadi akta dibawah tangan saja dan tidak mempunyai kekuatan hukum.

Prinsip kehati-hatian dapat diartikan sebagai dasar tentang kebenaran yang menjadi landasan berpikir dan bertindak dengan penuh sikap hati-hati.7 PPAT dalam melakukan tugas jabatannya membuat akta tersebut harus memperhatikan konsekuensi atau akibat yang akan datang dikemudian hari oleh karenanya diperlukan prinsip kehatihatian untuk menghindari permasalahan yang timbul setelah dibuatkannya akta oleh PPAT, dapat diartikan bahwa prinsip kehati-hatian memiliki tujuan untuk mengantisipasi dan melakukan pencegahan sejak awal terjadinya suatu akibat yang tidak pasti dari suatu kegiatan tertentu yang dilakukan oleh manusia. ${ }^{8}$

Permasalahan yang kedua, Pengadilan Tinggi Yogyakarta telah menganalisis perbuatan melawan hukum yang dilakukan oleh Tergugat I, Tergugat II, dan Tergugat III yang berupa penyalahgunaan keadaan terhadap diri Penggugat I Badirah yang sudah lanjut usia yang dalam keadaan sakit, tinggal sendirian dan tidak bisa baca tulis dengan dibohongi kata-kata oleh Tergugat II bahwa tanah tidak dijual hanya untuk menyelamatkan Pakde Sudiro / Penggugat II sehingga akhirnya terjadi jual beli tanah SHM No.03245/Wedomartani, Sleman dengan Badirah / Penggugat I membubuhkan cap jempol dan Tergugat III menandatangani Akta Jual Beli Nomor 14/2008, 13 Agustus 2008.

Berdasarkan ketentuan Pasal 1320 KUHPerdata yang berisi syarat sah perjanjian, ada syarat "kesepakatan mereka yang mengikatkan dirinya", bila dikaitkan dengan kasus diatas maka syarat ini ada hubungannya dengan perbuatan melawan hukum diatas. Kesepakatan harus terjadi berdasarkan kebebasan berkehendak. Pasal 1321 KUHPerdata lebih lanjut mengatur bahwa "Tiada sepakat yang sah apabila sepakat itu hlm. 19.

${ }^{7}$ Rachmadi Usman, Aspek-Aspek. Hukum Perbankan Indonesia, Gramedia Pustaka Umum, Jakarta, 2003,

${ }^{8}$ Sri Wartini, "Implementasi Prinsip Kehati-hatian Dalam Sanitary and Phythosanitary Agreement, Studi Kasus: Keputusan Appellate Body WTO Dalam Kasus Hormone Beef antara Uni Eropa dengan Amerika Serikat", Jurnal Hukum, No. 2 Vol. 14 April 2007, hlm. 296-313. 
diberikan karena kekhilafan (dwaling), atau diperoleh dengan paksaan (dwang) atau penipuan (bedrog)". Ketentuan Pasal 1321 tersebut jelas mengatakan kalau kesepakatan yang diperoleh dengan kekhilafan (dwaling), paksaan (dwang), dan penipuan (bedrog) adalah tidak sah, yang berarti perikatan atau perjanjian tersebut tidak sah.

Sepakat yang sah adalah sepakat yang diberikan tanpa ada unsur kekhilafan, paksaan, dan penipuan. Hal ini karena di dalam kasus tersebut Nyonya Badirah yang sudah lanjut usia yang dalam keadaan sakit, tinggal sendirian dan tidak bisa baca tulis dengan dibohongi kata-kata oleh Tergugat II kemudian terjadilah jual beli tanah SHM atas nama Nyonya Badirah. Hal itu membuat peneliti semakin yakin bahwa perikatan yang dilakukan antara Tergugat II dengan Nyonya Badirah telah melanggar Pasal 1320 KUHPerdata, yang mana karena telah melanggar syarat subjektif maka perikatan atau perjanjian tersebut dapat dibatalkan.

Ketentuan lebih lanjut yang memperkuat landasan mengenai Nyonya Badirah telah dibohongi dengan kata-kata oleh tergugat yang mana mengakibatkan perikatan atau perjanian tersebut batal adalah merujuk pada Pasal 1328 KUHPerdata yang berbunyi "Penipuan merupakan suatu alasan untuk membatalkan suatu persetujan, bila penipuan yang dipakai oleh salah satu pihak adalah sedemikian rupa, sehingga nyata bahwa pihak yang lain tidak akan mengadakan perjanjian itu tanpa adanya tipu muslihat, penipuan tidak hanya dapat dikira-kira melainkan harus dibuktikan". Jelas bahwa Pasal 1328 tersebut menjelasakan bahwa penipuan (bedrog) merupakan suatu alasan untuk membatalkan suatu perjanjian.

Selain pasal tersebut juga disebutkan dalam Pasal 1449 KUHPerdata yang berbunyi "perikatan yang dibuat dengan paksaan, penyesatan atau penipuan, menimbulkan tuntutan untuk membatalkannya". Menurut perkembangan hukum yang dikembangkan lewat putusan peradilan dikenal juga asas "penyalahgunaan keadaan".

Berdasarkan penjabaran kasus diatas dan pembahasan atau analisa dengan berbagai pertimbangan yang telah disebutkan diatas, peneliti setuju dan sudah tepat dasar pertimbangan hukum yang digunakan oleh Hakim Pengadilan Tinggi Yogyakarta dalam memutus perkara Nomor 93/Pdt/2016/PT. Yk. Berdasarkan dasar hukum perbuataan melawan hukum dan penyalahgunaan keadaan yang dilakukan oleh Sugito (Tergugat I), Puji Prasetyo Ningsih (Tergugat II), dan Andrianto Swandaru (Tergugat III) terhadap Badirah Sudiharjo (Penggugat I) yang mengakibatkan terjadinya Jual beli Tanah SHM No. 03245/Wedomartani tersebut. Hakim Pengadilan Tinggi Yogyakarta dalam memutus perkara ini untuk PT. BPR Bhakti Daya Ekonomi (Tergugat IV) juga sudah tepat dengan menggunakan dasar hukum bahwa PT. BPR Bhakti Daya Ekonomi tidak melakukan prinsip kehati-hatian sebagaimana diatur didalam Pasal 2 Undang-Undang Nomor 7 Tahun 1992 juncto Undang-Undang Nomor 10 Tahun 1998 tentang Perbankan yang berbunyi "Perbankan Indonesia dalam melakukan usahanya berasakan demokrasi ekonomi dengan menggunakan prinsip kehati-hatian". Ketentuan hukum Islam juga mengatur mengenai perjanjian, adapun perjanjian yang dibuat secara sah menurut hukum mempunyai 2 macam konsekuensi yuridis yaitu:

1. Bahwa perjanjian harus dilaksanakan oleh para pihak dengan sukarela dan dengan itikad baik. Dalam hal perjanjian tidak dilaksanakan oleh salah satu pihak atau terjadi 
wanprestasi, maka memberi hak-hak kepada pihak lain untuk menuntut ganti kerugian dan atau memutuskan perjanjian melalui pengadilan.

2. Bahwa perjanjian yang diabaikan oleh salah satu pihak, maka akan mendapat sanksi dari Allah SWT diakhirat kelak, hal ini menunjukan bahwa perjanjian yang dibuat oleh seorang muslim mempunyai implikasi baik di dunia maupun di akhirat.

Kasus di atas jika dihubungkan kedalam hukum perjanjian Islam juga telah melanggar asas hukum perjanjian dalam islam, yaitu asas Al-Hurriyah (Kebebasan), AlAdalah (Keadilan), dan asas Al-Ridha (Kerelaan) yaitu:

1. Al-Hurriyah (Kebebasan)

Asas kebebasan mengandung maksa tidak adanya suatu paksaan, seperti yang terkandung didalam Al-Qur'an Surat Al-Baqarah ayat 256 yang artinya,

"tidak ada paksaan untuk (memasuki) agama (islam), sesungguhnya telah jelas jalan yang benar daripada jalan yang sesat. karena itu barangsiapa yang ingkar kepada Thaghut dan beriman kepada Allah, maka sesungguhnya ia telah berpegang kepada buhul taliyang aman kuat yang tidak akan putus. dan Allah Maha mendengar lagi Maha mengetahui".

2. Al-Adalah (Keadilan)

Pelaksanaan atas asas ini didalam suatu perjanjian/akad menurut para pihak untuk melakukan yang benar dalam pengungkaann kehendak dan keadaan, memenuhi semua kewajibannya. perjanian harus senantiasa mendatangkan keuntungan yang adil dan seimbang, serta tidak boleh mendatangkan kerugian bagi salah satu pihak. Dasar hukum asas keadilan ini terdapat didalam Al-Qur'an Surat An-Nisa ayat 135, yang artinya,

"Wahai orang-orang yang beriman, jadilah kamu orang yang benar-benar penegak keadilan, menjadi saksi karena Allah biarpun terhadap dirimu sendiri atau ibu bapa dan kaum kerabatmu. Jika ia kaya ataupun miskin, maka Allah lebih tahu kemaslahatannya. Maka janganlah kamu mengikuti hawa nafsu karena ingin menyimpang dari kebenaran. Dan jika kamu memutar balikkan (kata-kata) atau enggan menjadi saksi, maka sesungguhnya Allah adalah Maha Mengetahui segala apa yang kamu kerjakan."

3. Asas Al-Ridha (Kerelaan)

Asas ini menyatakan bahwa segala transaksi yang dilakukan harus atas dasar kerelaan antara masing-masing pihak, harus didasarkan pada kesepakatan bebas dari para pihak dan tidak boleh ada unsur paksaan, tekanan, penipua, dan misstatemen. dasar hukum adanya asas kerelaan ini ada dialam Al-Qur'an Surat AnNisa ayat 29, yang artinya ,

"Hai orang-orang yang beriman, janganlah kamu saling memakan harta sesamamu dengan jalan yang batil, kecuali dengan jalan perniagaan yang berlaku dengan suka samasuka di antara kamu. Dan janganlah kamu membunuh dirimu; sesungguhnya Allah adalah Maha Penyayang kepadamu."

Berdasarkan penjelasan asas-asas perjanjian dalam Islam di atas, Tergugat I, II, dan III telah melanggar asas hukum perjanjian dalam islam, yaitu asas Al-Hurriyah (Kebebasan), Al-Adalah (Keadilan), dan asas Al-Ridha (Kerelaan), telah dijelaskan dalam 3 asas tersebut tidak boleh adanya suatu paksaan dalam membuat suatu perjanjian, harus mengedepankan keadilan dimana tidak boleh merugikan satu pihak, kemudian para pihak harus ada kerelaan harus ada kesepakatan bebas dari para pihak dan tidak mengandung unsur paksaan. Jika dihubungkan dengan kasus diatas yang mana Tergugat I, II, dan III telah melakukan perbuatan melawan hukum dan penyalahgunaan kehendak kepada Badirah (Penggugat I) seperti telah dijelaskan di atas. 


\section{Penutup}

Berdasarkan uraian di atas, terdapat 2 kesimpulan dalam penelitian ini, pertama, penerapan prinsip kehati-hatian wajib dan harus dilakukan dan diterapkan oleh pejabat pembuat akta tanah dalam menjalankan tugas jabatanya sesuai ketentuan Pasal 22 Peraturan Pemerintah Nomor 37 Tahun 1998 dan Kode Etik PPAT Pasal 3 tentang kewajiban. PPAT dalam membuat akta jual beli hak atas tanah dan akta pemberian hak tanggungan, PPAT harus lebih mengekspresikan diri dan mempunyai rasa ingin tahu yang berlebih sepanjang masih berkaitan dengan pembuatan kedua akta tersebut agar supaya tidak terjadi sengekta atau salah satu pihak mengalami kerugian atas akta yang dibuat tersebut. jika PPAT tidak bertindak hati-hati yang mengaibatkan kerugian salah satu pihak dalam kata nya tersebut maka akta tersebut dapat dibatalkan atau batal demi hukum yang mengakibatkkan ata PPAT menjadi akta di bawah tangan dan tidak mempunyai kekuatan hukum.

Kedua, dasar pertimbangan hukum yang digunakan oleh hakim dalam memutus perkara pembatalan akta jual beli hak atas tanah dan akta pemberian hak tanggungan yang tertuang dalam pertimbangan hakim yaitu perbuatan melawan hukum (Pasal 1365 KUHPerdata) dan penyalahgunaan keadaan. Dasar hukum yang digunakan hakim tersebut sudah tepat karena berkaitan dengan proses jual beli hak atas tanah diatas yang sudah dibuktikan di persidangan dengan saksi dan alat bukti lainnya, Tergugat I, II, dan III memang telah terbukti melakukan perbuatan melawan hukum (Pasal 1365 KUHPerdata) dan penyalahgunaan keadaan yang dilakukan kepada Badirah (Pengugat I) karena kondisinya yang sudah tua sedang sakit dan tidak bisa baca tulis serta ditakut-takuti dengan kata bohong sehingga terjadilah jual beli hak atas tanah tersebut. Hakim mengakatan oleh karena perjanjian jual beli tersebut dilakukan atas dasar perbuatan melawan hukum dan penyalahgunaan kehendak maka perjanjian tersebut beserta akta jual beli hak atas tanah dan akta pemberian hak tanggungan menjadi tidak ada kekuatan hukum. Menurut peneliti, perjanjian jual beli tersebut juga telah melanggar syarah sah perjanjian yaitu pada syarat subjektif dan oleh karena itu perjanjian tersebut dapat dibatalkan.

Berdasarkan uraian kesimpulan di atas, penulis memberikan 2 saran yakni, pertama, dalam menjalankan tugas jabatan sebagai PPAT khususnya dalam pembuatan akta jual beli dan akta pemberian hak tanggungan, PPAT harus dan wajib melaksanakan atau menerapkan prinsip kehati-hatian, agar supaya tidak terjadi sengketa dan mengakibatkan kerugian terhadap para pihak yang datang dihadapan PPAT. PPAT dalam penerapan prinsip kehati-hatian harus berinovasi dan kreatif serta detail menanyakan hal-hal yang terkait dengan akta yang dibuatnya, apabila msaih dirasa kurang puas terhadap jawaban atau ketarangan para pihak, PPAT atau diwakilkan staf PPAT dapat mengecek dan meneliti langsung ke obyek jual beli yang bersangkutan untuk memperoleh bukti baik secara formil dan materilnya serta meyakinkan PPAT sebelum membuat akta.

Kedua, dalam memutus suatu perkara, hakim memiliki asas-asas putusan yang harus diterapkan didalam putusan yaitu memuat dasar alasan yang jelas dan rinci, wajib mengadli seluruh bagian gugatan, tidak boleh mengabulkan melebihi tuntutan, dan diucapkan di muka umum. Hakim Pengadilan Tinggi Yogyakarta sudah menerapkan 
asas-asas tersebut, peneliti memberikan sedikit saran yaitu dalam pembahasan mengenai penyalahgunaan kehendak seharusnya ditambah penjelasan yang lebih detail lagi.

\section{Daftar Pustaka}

\section{Buku}

Adjie, Habib, Sanksi perdata dan Administratif Terhadap Notaris Sebagai Pejabat Publik, Refika Aditama, Bandung, 2009.

Badrulzaman, Darus Mariam, Kompilasi Hukum Perikatan, PT. Citra Aditya Bakti, Bandung, 2001.

Darus, Luthfan Hadi, Hukum Notariat dan Tanggungjaab Jabatan Notaris, UII Press, Yogyakarta, 2017.

H.R., Ridwan, Hukum Administrasi Negara, Raja Grafindo Persada, Jakarta, 2006.

Kansil, C. S. T, Pengantar Hukum dan Tata Hukum Indonesia, Balai Pustaka, Jakarta, 1989.

Marzuki, Peter Mahmud, Penelitian Hukum, Kencana, Jakarta, 2017.

Muhammad Abdulkadir, Hukum dan Penelitian Hukum, Citra Aditya Bakti, Bandung, 2004. Hukum Perusahaan Indonesia, Citra Aditya Bakti, Bandung, 2010.

Pasaribu Chairuman \& Suhrawadi K Lubis, Hukum Perjanjian Dalam Islam, Sinar Grafika, Jakarta, 2004.

Soerodjo, Irawan, Kepastian Hukum Hak Atas Tanah di Indonesia, Arkola, Surabaya, 2003.

Tedjosaputro, Liliana, Etika Profesi Notaris dalam Penegakan Hukum Pidana, Bayu Indra Grafika, Yogyakarta, 1995.

Samsaimun, Peraturan Jabatan PPAT, Pustaka Reka Cipta, Bandung, 2018.

Usman, Rachmadi, Aspek-Aspek Hukum Perbankan Indonesia, Gramedia Pustaka Umum, Jakarta, 2003.

\section{Jurnal}

Ariesta R, Fikri, "Penerapan Prinsip Kehati-hatian Notaris Dalam Mengenal Para Pihak", Lex Renaissance, Vol. 3, No. 2, 2018.

Wartini, Sri, "Implementasi Prinsip Kehati-hatian Dalam Sanitary and Phythosanitary Agreement", Studi Kasus Keputusan Appellate Body WTO Dalam Kasus Hormone Beef antara Uni Eropa dengan Amerika Serikat, Jurnal Hukum, Vol. 14, No. 2, April, 2007.

\section{Peraturan Perundang-Undangan}

Peraturan Kepala Badan Pertanahan Nasional Republik Indonesia Nomor 1 Tahun 2006 tentang Ketentuan Pelaksanaan Peraturan Pemerintah Nomor 37 Tahun 1998 tentang Peraturan Jabatan Pejabat Pembuat Akta Tanah.

\section{Putusan Pengadilan}

Putusan Pengadilan Tinggi Yogyakarta Nomor 93/Pdt/2016/PT.Yyk 